\title{
SIMULATION OF FIRE SPREAD BETWEEN RESIDENTIAL BUILDINGS REGARDING SAFE SEPARATION DISTANCE
}

\author{
Dusica Pesic, Darko Zigar, Miomir Raos, Ion Anghel
}

Original scientific paper

Determination of optimal safe distance between buildings is a task of many safety and economic analyses. Generally, it is known that increasing separation distance increases fire protection of an adjacent building, but decreases the cost effectiveness of urban solutions. For this reason, CFD Large Eddy Simulation method of Fire Dynamics Simulator software package has been used in this paper to determine optimal separation distance required for preventing fire spread between two residential buildings facing each other. The minimum conditions necessary for ignition of the window curtains in the fire-exposed building located at different building distances $(3,5 \mathrm{~m}, 4,0 \mathrm{~m}$ and 4,5 $\mathrm{m})$ were analysed. The obtained results show that the fire does not spread at the distance of $4,5 \mathrm{~m}$, and that the incident heat flux at the curtain surface is higher than the critical heat flux value of $12,6 \mathrm{~kW} / \mathrm{m}^{2}$ adopted in many building codes.

Keywords: fire spread; LES method; residential building; separation distance

Simulacija širenja vatre između stambenih zgrada u odnosu na sigurnu udaljenost

Izvorni znanstveni članak

Određivanjem optimalne sigurne udaljenosti između zgrada bave se mnoge sigurnosne i ekonomske analize. Općenito je poznato da se povećanjem razmaka povećava zaštita od širenja vatre na susjednu zgradu, ali se smanjuje isplativost urbanih rješenja. Iz tog se razloga u ovom radu koristi programski paket CFD Large Eddy Simulation method of Fire Dynamics Simulator kako bi se odredila optimalna udaljenost potrebna da bi se spriječilo širenje vatre izmđu dviju stambenih grada okrenutih jedne drugoj. Analizirali su se minimalni uvjeti potrebni da bi se zapalile zavjese na prozorima zgrade izložene vatri smještenoj na raznim udaljenostima $(3,5 \mathrm{~m}, 4,0 \mathrm{~m}$ i 4,5 m). Dobiveni rezultati pokazuju da se na udaljenosti od 4,5 m vatra ne širi i da je ulazna količina topline na površini zavjese veća od vrijednosti kritične količine topline od $12,6 \mathrm{~kW} / \mathrm{m}^{2}$ prihvaćene $\mathrm{u}$ mnogim graditeljskim kodeksima.

Ključne riječi: LES metoda; stambena zgrada; širenje vatre; udaljenost između zgrada

\section{Introduction}

The fire spreading from a burning residential building to adjacent buildings can occur in a number of different ways such as flame contact, flying brands emitted from a building on fire etc. Convective heat transfer may also result in the ignition of an exposed building if it is located very close to the fire. However, in most cases, the fire from a burning building spreads out through the exterior openings and then continues to spread to the adjacent buildings, due to flame radiation. Fire spread via openings depends on the separation distance between the buildings, their orientation to each other, the fact whether the windows in the adjacent building are closed as well as on the percentage of openings in both the building on fire and the exposed building. The heat transfer by radiation from a burning building to a receiving surface of an adjacent building depends on several factors such as projections of flames from the openings, the emissivity of the flame and the configuration factor, as well as the distance between the buildings. Radiative heat flux at the exposed facade of an adjacent building is very important parameter as well.

Therefore, the risk of fire or the spread of fire is an important factor that must be taken into account while determining the minimum separation distance between buildings. Three important parameters with regard to determining safe separation distances are: the predicted fire temperature, the levels of emitted radiation from the burning building and the levels of radiation that may ignite the flammable materials both on the facade and within the exposed building due to radiation entering through the windows. By knowing the conditions under which materials ignite and the quantity of radiation at various distances from a burning building, it is possible to arrive at optimal safe separation distances between adjacent buildings. The determination of the optimal separation distance between buildings is a task of economic and safety analyses, although it is known that with the increasing separation distance, the fire protection of an adjacent building increases, but the cost effectiveness of urban solutions decreases.

In many countries, the separation distances between residential buildings are recommended by different Building Codes $[1 \div 4]$. The Codes give different calculation methods for determining the buildings separation distance based on the maximum tolerable radiation level on the fire-exposed building facade. In fire protection engineering, radiative heat transfer mechanisms are accounted for with different levels of accuracy ranging from roughly simplified analyses from strictly empirical models, semi-empirical models, and theoretical models to sophisticated methods of investigation. The computer technology growth has led to the development of large numbers of computational models applied to fire studies and heat transfer mechanisms. Since the Computational Fluid Dynamics (CFD) techniques are fast and the results can be obtained at almost no cost [5], they are often used for modelling of fire dynamics and radiation simulations. CFD techniques include Reynolds-averaged Navier-Stokes equation (RANS) method, Large Eddy Simulation (LES) and Direct Numerical Simulation (DNS). LES has been widely applied to simulate the fire-induced flow, because it is a CFD method which is capable of predicting unsteadiness in turbulent flows. In past decades, several commercial CFD software packages such as ANSYS FLUENT, ANSYS CFX, PHOENICS, SMARTFIRE etc.

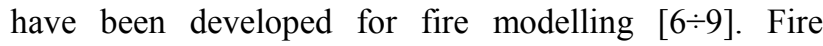


Dynamics Simulator (FDS) as open-source CFD software package is widely used for fire related studies, because it is suitable for a wide range of thermally driven flow scenarios both an outdoors and inside a built environments [10].

Taking the above mentioned in mind, a few methods applied to determine the safe separation distance between buildings have been analysed in this paper. In order to determine the optimal separation distance, the FDS LES method has been used for simulations of fire spread between two residential buildings.

\section{Building codes - fire separation distances}

There is no internationally accepted method used for buildings' design which takes into account the external fire spread between buildings. Many National Building Codes are generally based on more or less prescriptive provisions, without any background about their origin. In these codes, different calculation methods for determining the safe separation distance between the buildings and acceptable unprotected areas have been given. A value of approximately $12,6 \mathrm{~kW} / \mathrm{m}^{2}$ is used in calculation methods as the maximum tolerable level of radiation at the exposed building facade to fire. The objective of many calculation methods is that the building is separated from the relevant boundary by at least half the distance at which the total radiant heat flux received from all unprotected areas in the external wall would be 12,6 $\mathrm{kW} / \mathrm{m}^{2}$. This is based on the assumption that the emitted radiation from the unprotected areas in the wall is 84 $\mathrm{kW} / \mathrm{m}^{2}$ for the residential, office and recreation buildings, and $168 \mathrm{~kW} / \mathrm{m}^{2}$ for the industrial, storage, commercial or other non-residential buildings $[1 \div 3]$. The method is also called the "mirror image concept", which means that two similar buildings, one the mirror image of the other are located equidistant from either side of the relevant boundary (Fig. 1).

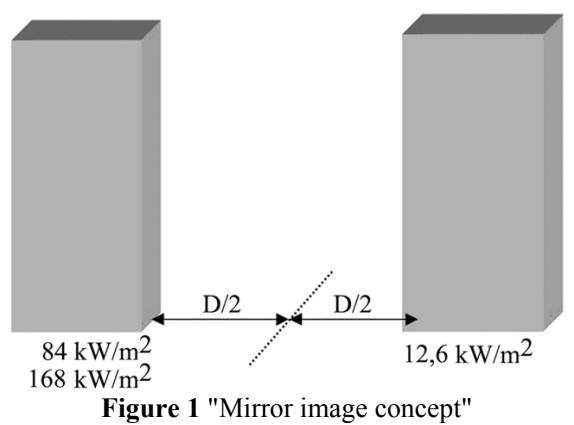

In England, the requirements regarding external fire spread and the methods for calculating the separation distances between buildings are set out in the Building Regulations [1]. The distance from the relevant boundary and the maximum acceptable unprotected areas are calculated using two methods. Method 1 is used for calculating the distance between dwelling houses, flats and other residential buildings. The external walls of these types of buildings cannot be longer than $24 \mathrm{~m}$, and the buildings should not be more than three levels/floors in height. Fig. 2 shows the principles of method 1 and the distance to the relevant boundary. The minimum distances from the relevant boundary to the sides of the building and the maximum acceptable unprotected areas are shown in Tab. 1. Method 2 can be used for any building whose height is not higher than $10 \mathrm{~m}$. The distances from the relevant boundary to the side of the building and maximum acceptable unprotected areas are given in Tab. 2 .

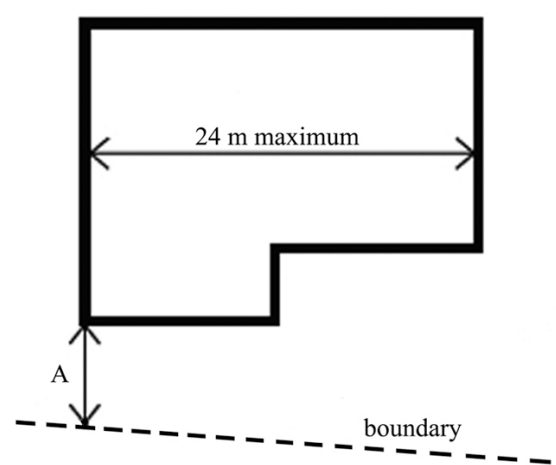

Figure 2 Principles of method 1

Table 1 Separation distances and maximum unprotected areas (method 1)

\begin{tabular}{|c|c|}
\hline $\begin{array}{c}\text { Minimum distance between external wall } \\
\text { and relevant boundary }(\mathrm{m})\end{array}$ & $\begin{array}{c}\text { Maximum acceptable } \\
\text { unprotected area }\left(\mathrm{m}^{2}\right)\end{array}$ \\
\hline 1,0 & 5,6 \\
\hline 2,0 & 12,0 \\
\hline 3,0 & 18,0 \\
\hline 4,0 & 24,0 \\
\hline 5,0 & 30,0 \\
\hline 6,0 & No limit \\
\hline
\end{tabular}

Table 2 Separation distances and maximum unprotected areas (method 2)

\begin{tabular}{|c|c|c|}
\hline $\begin{array}{c}\text { Separation distance between external wall and } \\
\text { relevant boundary }(\mathrm{m})\end{array}$ & $\begin{array}{c}\text { Maximum } \\
\text { unprotected area as } \\
\text { a percentage of total } \\
\text { wall area (\%) }\end{array}$ \\
\cline { 1 - 2 } $\begin{array}{c}\text { Residential, office, } \\
\text { assembly, recreation } \\
\text { buildings }\end{array}$ & $\begin{array}{c}\text { Shop, commercial, } \\
\text { industrial, storage, other } \\
\text { non-residential buildings }\end{array}$ & 4,0 \\
\hline- & 1,0 & 8,0 \\
\hline 1,0 & 2,0 & 20,0 \\
\hline 2,5 & 5,0 & 40,0 \\
\hline 5,0 & 10,0 & 60,0 \\
\hline 7,5 & 15,0 & 80,0 \\
\hline 10,0 & 20,0 & 100,0 \\
\hline 12,5 & 25,0 & \\
\hline
\end{tabular}

In the United States of America, the NFPA 80A code recommends separation distances between buildings to limit exterior fire spread based on exterior openings and other construction features [4]. These recommendations are intended to provide a reasonable level of protection for combustible materials within and on the exterior facade of a building exposed to an external building fire. Separation distances are determined assuming that the facade of an unprotected exposed building is constructed of cellulosic materials, with the ability to withstand ignition when exposed to a maximum radiation level of $12,5 \mathrm{~kW} / \mathrm{m}^{2}$. The buildings are classified into three groups according to the hazard: light, moderate and severe, depending on classification of fire load and flame spread. Depending on these parameters, a safe distance can be calculated by using guide numbers (Tab. 3). In order to determine distances, the lesser dimension of either width or height should be multiplied by the guide number and then added $1,52 \mathrm{~m}$ that takes into account the flame projections out of openings and the ignition prevention due to flame impingement on the exposed building. 
Table 3 Guide numbers for minimum separation distance (NFPA 80A)

\begin{tabular}{|c|c|c|c|c|c|c|c|c|c|c|c|c|c|c|c|c|c|c|c|}
\hline \multicolumn{3}{|c|}{ Fire severity } & \multicolumn{17}{|c|}{ Guide number } \\
\hline \multicolumn{3}{|c|}{ Percentage of openings } & \multicolumn{17}{|c|}{ Width/height or height/width } \\
\hline Light & Moderate & Severe & 1,0 & 1,3 & 1,6 & 2,0 & 2,5 & 3,2 & 4,0 & 5,0 & 6,0 & 8,0 & 10 & 13 & 16 & 20 & 25 & 32 & 40 \\
\hline 20 & 10 & 5 & 0,36 & 0,40 & 0,44 & 0,46 & 0,48 & 0,49 & 0,50 & 0,51 & 0,51 & 0,51 & 0,51 & 0,51 & 0,51 & 0,51 & 0,51 & 0,51 & 0,51 \\
\hline 30 & 15 & 7,5 & 0,60 & 0,66 & 0,73 & 0,79 & 0,84 & 0,88 & 0,90 & 0,92 & 0,94 & 0,94 & 0,94 & 0,95 & 0,95 & 0,95 & 0,95 & 0,95 & 0,95 \\
\hline 40 & 20 & 10 & 0,76 & 0,85 & 0,94 & 1,02 & 1,10 & 1,18 & 1,23 & 1,27 & 1,30 & 1,32 & 1,33 & 1,33 & 1,34 & 1,34 & 1,34 & 1,34 & 1,34 \\
\hline 50 & 25 & 12,5 & 0,90 & 1,00 & 1,11 & 1,22 & 1,33 & 1,42 & 1,51 & 1,58 & 1,63 & 1,66 & 1,69 & 1,71 & 1,71 & 1,71 & 1,71 & 1,71 & 1,71 \\
\hline 60 & 30 & 15 & 1,02 & 1,14 & 1,26 & 1,39 & 1,52 & 1,64 & 1,76 & 1,85 & 1,93 & 1,99 & 2,03 & 2,08 & 2,08 & 2,08 & 2,08 & 2,08 & 2,08 \\
\hline 80 & 40 & 20 & 1,22 & 1,37 & 1,52 & 1,68 & 1,85 & 2,02 & 2,18 & 2,34 & 2,48 & 2,59 & 2,67 & 2,80 & 2,80 & 2,79 & 2,80 & 2,81 & 2,81 \\
\hline 100 & 50 & 5 & 1,39 & 1,56 & 1,74 & 1,93 & 2,13 & 2.34 & 2,55 & 2,76 & 2,95 & 3,12 & 3,26 & 3,36 & 3,43 & 3,48 & 3,51 & 3,52 & 3,53 \\
\hline- & 60 & 30 & 1,55 & 1,73 & 1,94 & 2,15 & 2,38 & 2,63 & 2,88 & 3,13 & 3,37 & 3,60 & 3,79 & 3,95 & 4,07 & 4,15 & 4,20 & 4,22 & 4,24 \\
\hline- & 80 & 40 & 1,82 & 2,04 & 2,28 & 2,54 & 2,82 & 3,12 & 3,44 & 3.77 & 4,11 & 4,43 & 4,74 & 5,01 & 5,24 & 5,41 & 5,52 & 5,60 & 5,64 \\
\hline- & 100 & 50 & 2,05 & 2,30 & 2,57 & 2,87 & 3,20 & 3,55 & 3,93 & 4,33 & 4,74 & 5,16 & 5,56 & 5,95 & 6,29 & 6,56 & 6,77 & 6,92 & 7,01 \\
\hline- & - & 60 & 2,26 & 2,54 & 2,84 & 3,17 & 3,54 & 4,93 & 4,36 & 4,82 & 5,30 & 5,80 & 6,30 & 6,78 & 7,23 & 7,63 & 7,94 & 8,18 & 8,34 \\
\hline- & - & 80 & 2,63 & 2,95 & 3,31 & 3,70 & 4,13 & 4,61 & 5,12 & 5,68 & 6,28 & 6,91 & 7,57 & 8,24 & 8,89 & 9,51 & 10,05 & 10,50 & 10,84 \\
\hline- & - & 100 & 2,96 & 3,32 & 3,72 & 4,16 & 4,65 & 5,19 & 5,78 & 6,43 & 7,13 & 7,88 & 8,67 & 9,50 & 10,33 & 11,15 & 11,91 & 12,59 & 13,15 \\
\hline
\end{tabular}

In Croatia, prevention of fire spread and safe separation distances between buildings are proposed by the Law on Fire Protection, the Law on Construction, the Law on Local and Regional Self-Governments, Regulations on construction sites for which the fire protection authority is not issuing the decisions on construction requirements i.e. location permits and Municipal Spatial Plans $[11 \div 14]$ Municipal Spatial Plans propose that the minimum distance of building from the neighbouring border must be equal to at least half of the height of a building, but no less than $3 \mathrm{~m}[15 \div 17]$.

In Serbia, separation distances between buildings are proposed by the Law on Fire Protection, the Law on Planning and Construction, Regulations on general standards for lotting and construction, contents, conditions and procedure for the issuance of acts on zoning requirements that require municipal or city permit, as well as Technical recommendation for structural fire protection for residential, business and public buildings $[18 \div 21]$. Regulations on general standards for lotting and construction, contents, conditions and procedure for the issuance of acts on zoning requirements that require municipal or city permit prescribe the minimum distances between the objects. The distances between multi-storey buildings and buildings that are built in a row must be equal to at least half of the higher building height. If the buildings at the opposing side facades do not contain windows, the distance can be reduced to a quarter of the height of a higher building. This distance cannot be less than $4 \mathrm{~m}$ if one of the buildings walls contains windows. The minimum distance between family housing must be 4 $\mathrm{m}$. Technical recommendation for structural fire protection for residential, business and public buildings prescribes the methodology for determination of the separation distance between the buildings. Considering the possibility of fire spread, the separation distance between buildings (i.e. their nearest windows) can be determined by the conditions necessary for ignition of the curtains on the window of the adjacent building caused by the flame radiation through the windows of the burning building. At the same time, during time interval of $30 \mathrm{~min}$, radiative heat flux on the curtain surface must be less than $8 \mathrm{~kW} / \mathrm{m}^{2}$ [21].

\section{Methodology}

\subsection{Numerical method}

The investigation of fire spread between two residential buildings was carried out using the FDS software package, developed by the National Institute of Standards and Technology (USA). The hydrodynamic model within FDS solves numerically a low Mach number form of the Navier-Stokes equations appropriate for thermally-driven flows, as follows [22]

Conservation of mass

$\frac{\partial \rho}{\partial t}+\nabla \cdot \rho \boldsymbol{u}=\dot{m}_{b}^{\prime \prime \prime}$

which is often written in terms of the mass fractions of the individual gaseous species

$$
\frac{\partial}{\partial t}\left(\rho Y_{\alpha}\right)+\nabla \cdot \rho Y_{\alpha} \boldsymbol{u}=\nabla \cdot \rho D_{\alpha} \nabla Y_{\alpha}+\dot{m}_{\alpha}^{\prime \prime \prime}+\dot{m}_{\mathrm{b}, \alpha}^{\prime \prime}
$$

Conservation of momentum

$\frac{\partial}{\partial t}(\rho \boldsymbol{u})+\nabla \cdot \rho \boldsymbol{u} \boldsymbol{u}+\nabla p=\rho \boldsymbol{g}+\boldsymbol{f}_{\mathrm{b}}+\nabla \cdot \tau_{i j}$

Transport of sensible enthalpy

$$
\frac{\partial}{\partial t}\left(\rho h_{s}\right)+\nabla \cdot \rho h_{s} \boldsymbol{u}=\frac{D p}{D t}+\dot{q}^{\prime \prime \prime}-\dot{q}_{b}^{\prime \prime \prime}-\nabla \cdot \dot{\boldsymbol{q}}^{\prime \prime}+\varepsilon
$$

where: $\rho$ is density, $\boldsymbol{u}$ is velocity vector, $\boldsymbol{u}=[u, v, w]^{\mathrm{T}}, Y_{\alpha}$ is mass fraction of $\alpha^{\text {th }}$ species, $\dot{m}_{\alpha}^{\prime \prime \prime}$ is mass production rate per unit volume of species $\alpha$ by chemical reactions, $\dot{m}_{b, \alpha}^{\prime \prime \prime}$ is production of species $\alpha$ by evaporating particles; $\dot{m}_{b}^{\prime \prime \prime}=\sum_{\alpha} \dot{m}_{b, \alpha}^{\prime \prime \prime}$

is production rate of species by evaporating droplets/particles, $D_{\alpha}$ is diffusion coefficient, $p$ is pressure, $\boldsymbol{g}$ is gravity vector, $(0 ; 0 ;-g), \boldsymbol{f}_{\mathrm{b}}$ is external force vector, $\boldsymbol{u} \boldsymbol{u}$ is diadic tensor, $\tau_{i j}$ is stress tensor, $h_{\mathrm{s}}$ is sensible enthalpy, $\dot{q}^{\prime \prime}$ is heat flux vector, $\dot{q}^{\prime \prime}$ is heat release rate per unit volume from a chemical reaction, $\dot{q}_{b}^{\prime \prime \prime}$ is energy transferred to the evaporating droplets, $\varepsilon$ is dissipation rate and $t$ is time.

Eqs. $(1) \div(4)$ can be treated as DNS or LES methods. In this study, LES method with a refined Smagorinsky Sub-Grid Scale (SGS) turbulence model [23] was chosen to predict the sub-grid scale motion of viscosity, thermal 
conductivity, and material diffusivity of the fluid. The fluids' thermal conductivity and material diffusivity are related to the viscosity in terms of the Prandtl number and the Schmidt number. For purpose of the investigation, Smagorinsky constant was set as low value (i.e. 0,2), while turbulent Prandtl number and Schmidt number were both constant with value of 0,5 .

Energy transport (Eq. (4)) consists of convection, conduction and radiation. Convection of heat is accomplished via the solution of the basic conservation equations. Gains and losses of heat via conduction and radiation are represented by the divergence of the heat flux vector, $\nabla \cdot \dot{\boldsymbol{q}}^{\prime \prime}$, in the energy equation. The equation associated with the radiative part, $\nabla \cdot \dot{\boldsymbol{q}}_{\mathrm{r}}^{\prime \prime}$ is the Radiative Transport Equation (RTE) for an absorbing, emitting, and scattering medium, as follows [22]

$$
\begin{aligned}
& s \cdot \nabla I_{\lambda}(x, s)=-\left[k(x, \lambda)+\sigma_{s}(x, \lambda)\right] I_{\lambda}(x, s)+ \\
& +B(x, \lambda)+\frac{\sigma_{\mathrm{s}}(x, \lambda)}{4 \pi} \int_{4 \pi} \Phi\left(s, s^{\prime}\right) I_{\lambda}\left(x, s^{\prime}\right) \mathrm{d} s^{\prime}
\end{aligned}
$$

where: $I_{\lambda}(x, s)$ is radiation intensity at wavelength $\lambda, s$ is direction vector of the intensity, $k(x, \lambda)$ is local absorption coefficient, $\sigma_{\mathrm{s}}(x, \lambda)$ is scattering coefficient, $B(x, \lambda)$ is emission source term, describing how much heat is emitted by the local mixture of gas, soot and droplets/particles, $\Phi\left(s, s^{\prime}\right)$ is a scattering phase function that gives the scattered intensity from direction $s^{\prime}$ to $s$, i.e.

$$
\frac{\Phi\left(s, s^{\prime}\right) \mathrm{d} s^{\prime}}{4 \pi}
$$

FDS utilizes the Finite Volume Method (FVM) because the FVM is an ideal method for computing discontinuous solutions arising in compressible flows. FDS calculates the heat release rate, species concentrations, temperatures, velocities etc. within each numerical rectangular grid cell at each discrete time step. Since the fire is a strong buoyancy source and convective transport dominates diffusive transport, the CourantFriedrichs-Lewy (CFL) criterion is used for justifying the computational convergence. The estimated velocities are tested at each time step to ensure that the CFL condition is satisfied

$$
\delta t \cdot \max \left(\frac{\left|u_{i j k}\right|}{\delta x}, \frac{\left|v_{i j k}\right|}{\delta y}, \frac{\left|w_{i j k}\right|}{\delta z}\right)<1
$$

where $u, v$, and $w$ are components of the velocity of fluid flow in the smallest grid cell. The physical meaning of the convergence criteria is the following: when calculating the wave crossing a discrete grid, the time step must be less than the time for the wave to travel adjacent grid points. The initial time step is set automatically by the size of a grid cell divided by the characteristic velocity of the flow. The default value is $5(\delta x \delta y \delta z)^{1 / 3} /(g H)^{1 / 2}$, where $x, y$, and $z$ are spatial dimensions of the smallest mesh cell, $H$ is height of the computational domain, and $g$ is acceleration due to gravity.

\subsection{Simulation set-up}

FDS requires the following inputs: geometry of the facility, computational cell size, location of the ignition source, fuel type, heat release rate, material thermal properties, and boundary conditions.

\subsubsection{Model configuration}

Two residential buildings were designed for CFD LES simulations. The first two-storey burning building with dimensions of $9,5 \times 8,4 \times 7,8 \mathrm{~m}$ had the living room, the dining room and the kitchen at the ground floor and three bedrooms at the first floor. In order to reduce the volume of computational domain, only the part of the second identical building was designed at the right part of the domain. The buildings were "mirror images" of each other. Both buildings were built of concrete and wooden roof frame constructions. The surfaces of the internal walls and ceiling of the buildings were covered with gypsum boards. The building facades facing each other had three windows of dimensions $1,4 \times 1,4 \mathrm{~m}$ and wooden doors of dimensions $1,6 \times 2,0 \mathrm{~m}$. The thicknesses of structure materials and their thermodynamic data at normal temperature are given in Tab. 4 [22].

Table 4 Properties of structure materials at normal temperature

\begin{tabular}{|l|c|c|c|c|}
\hline \multicolumn{1}{|c|}{ Material } & $\begin{array}{c}\text { Thickness } \\
(\mathrm{m})\end{array}$ & $\begin{array}{c}\text { Density } \\
\left(\mathrm{kg} / \mathrm{m}^{3}\right)\end{array}$ & $\begin{array}{c}\text { Thermal } \\
\text { conductivit } \\
\mathrm{y}(\mathrm{W} / \mathrm{mK})\end{array}$ & $\begin{array}{c}\text { Specific heat } \\
\left(\mathrm{J} / \mathrm{kg}^{\circ} \mathrm{C}\right)\end{array}$ \\
\hline Concrete & 0,2 & 2100 & 1,0 & 880 \\
\hline Gypsum board & 0,13 & 1440 & 0,48 & 840 \\
\hline Wood & - & 750 & 0,14 & 2850 \\
\hline Glass & 0,003 & 2500 & 0,76 & 840 \\
\hline
\end{tabular}

The buildings are placed in a computational domain with dimensions of $19 \times 12 \times 9$ m (width $\times$ length $\times$ height). The ground level of the computational domain was set as a solid boundary. The top and the other three sides of the domain were set to be opened in order to simulate the real conditions for an open space. The space around the buildings was also set as outer space.

\subsubsection{Fire parameters}

Fire load mass (flammable materials) of the burning building consisted of wooden cabinets, tables, chairs, kitchen furniture and upholstered beds and armchairs with cotton pillows. Floors and stairs were covered with synthetic carpets. The cotton curtains were placed on the building windows. Properties of used materials are given in Tab. 5 .

Pool fire $(\varnothing 0,28 \mathrm{~m}$ pan with vegetable oil) as the initial fire source was set on the top of the cooking stove in the kitchen. For investigation of fire spread between adjacent buildings, it was very important to determine the fire severity, i.e. the quantity of thermal radiation passing through the openings and from the flame projected outside the burning building. In general, fire severity is dependent on several factors, such as the average fire load per unit floor area, properties of the furniture, as well as room geometries and opening dimensions (i.e. ventilation conditions). The average fire load within the burning building was assumed to be of the same size as is 
generally found in many residential buildings, i.e. 37 $\mathrm{kg} / \mathrm{m}^{2}$.

Table 5 Properties of fire load mass

\begin{tabular}{|c|c|c|c|c|c|}
\hline Material & 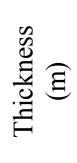 & 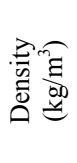 & 吾总 & 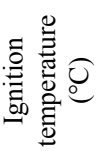 & 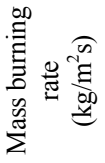 \\
\hline Spruce & 0,02 & 450 & 0,18 & 360 & 0,06 \\
\hline Upholstery & 0,002 & 100 & 0,1 & 350 & 0,03 \\
\hline Fabric foam & 0,250 & 30 & 0,034 & 350 & 0,03 \\
\hline Carpet & 0,006 & 750 & 0,16 & 290 & 0,05 \\
\hline $\begin{array}{l}\text { Pillows, } \\
\text { Curtains (Cotton) }\end{array}$ & 0,003 & 40 & - & 280 & 0,03 \\
\hline
\end{tabular}

According to BSI [24], the average heat release rate per unit area is $780 \mathrm{~kW} / \mathrm{m}^{2}$. Since it was assumed that the whole building was on fire, the total Heat Release Rate (HRR) was 12,5 MW. The growth phase of the fire was specified by the $t$-square fire growth model. In accordance with the NFPA 80A [4], it was assumed that the fire was of moderate severity.

\subsubsection{Boundary conditions}

Since the exterior boundaries of the computational domain, except the ground level, were set to be opened, the fire products can flow freely in and out the domain. The simple upwind boundary condition has been adopted; in case of incoming flow, the fire parameters take on their appropriate exterior values at the exterior boundaries and in case of outgoing flow, they take on appropriate values in the grid cells adjacent to the boundary. At external boundaries, the ambient pressure is set to be constant.

A tangential velocity boundary condition was used to set the velocity at the impermeable building walls. Theoretically, the velocity is zero at inert solid surfaces, but increases rapidly through a boundary layer (a few millimetres thick) to its free stream value. For many numerical studies, the adopted grid cells are too large to exactly resolve this boundary layer. To overcome this, a velocity boundary condition factor, known as the "slip" factor, was used to set the velocity at the building walls to be a fraction of their values in the adjoining cell. The halfslip condition was used since the finer grid requires longer computing time.

Considering the fact that the aim of this study was the possibility of ignition of the curtains located within opened windows due to fire radiation, the heat fluxes and the temperatures at their surfaces were analysed only. For this reason, the adiabatic boundary condition was adopted at the fire-exposed building wall, i.e. the radiative and convective heat fluxes were set to be zero.

\subsubsection{Numerical mesh}

For the LES applications a relatively high mesh resolution is required [25] because the obtained numerical solution of the equations is better if the numerical grid is finer. However, the fine grid needs powerful computational resources and longer computing time. Therefore, it is important to determine an appropriate grid size that would optimize the solution accuracy and time.
The quality of the mesh resolution depends on both the fire size and the grid cells size. The grid cell size depends on the HRR of the fire and the ambient air properties. These factors are combined to give a characteristic fire diameter $D^{*}$, as follows [22]

$$
D^{*}=\left(\frac{\dot{Q}}{\rho_{\infty} c_{p} T_{\infty} \sqrt{g}}\right)^{\frac{2}{5}} \text {. }
$$

where: $\dot{Q}$ is HRR, $c_{p}$ is specific heat of the smoke, $\rho_{\infty}$ is air density, $T_{\infty}$ is air temperature, and $g$ is acceleration due to gravity.

The grid size is determined by the non-dimensional expression $D^{*} / \delta x$ where $\delta x$ is the nominal cell size. In [22] the authors suggest that the mesh size must be no larger than $0,1 D^{*}$ to obtain viable simulation results. For the HRR of fire used in the simulations, the grid of $0,2 \mathrm{~m}$ can be taken as a reasonable grid size.

\subsubsection{Other simulation details}

For simulation the worst fire spread scenario through the window openings of burning building, it was assumed that the door and all the windows of the burning building were closed, while all windows of the adjoining building exposed to fire were open at the start of the simulations. The aim of the scenario was to determine the minimum conditions necessary for ignition of the cotton curtains on the windows of fire-exposed building; for this reason, the virtual radiometers are defined in points placed on the centers of the windows curtain surfaces of this building. The temperature of the radiometers was set to be $20{ }^{\circ} \mathrm{C}$. For each virtual radiometer a view factor is defined. The opening angle is $180^{\circ}$. The absorption and the sensitivity of $100 \%$ was assigned, i.e. it was considered that there is no heat loss to the recipients.

In general, the wind flow is a parameter that determines the air flow and consequently, the fire flame and plume flow in outdoor space. In this study, the impact of wind flow on fire spread and on emitted and recieved radiation was not investigated. The instantaneous or "real" wind was only specified, e.g., an initial velocity boundary condition of $0,3 \mathrm{~m} / \mathrm{s}$ with profile given by the power low $u=u_{o}\left(z / z_{o}\right)^{p}$, where $z_{o}=0 \mathrm{~m}$, and $p=0,2$ was set at the right side of the computational domain. The ambient temperature was set at $20{ }^{\circ} \mathrm{C}$ in the whole computational domain.

Duration of numerical simulations was $900 \mathrm{~s}$. The possibility of fire spreading in case of three different distances between buildings, i.e. 3,5 m, 4,0 $\mathrm{m}$ and 4,5 m was investigated here. These distance values were chosen in order to examine the validity of Serbian legislation under which the separation distance between these types of residential buildings must not be less than $4 \mathrm{~m}$.

\subsection{Model validation}

The validation study was conducted in Air Pollution Control Laboratory at the Faculty of Occupational Safety in Niš. The scale-reduced buildings model 1:50 was 
located in the closed loop wind tunnel. The reduced buildings were made out of the heat resistant glass panels.

Heat source in the fire building was the wooden briquettes which are distributed across the floor. Since the fire flame radiation influences the ignition of windows curtains, the numerical model was validated by comparing simulation results of the curtain surface temperatures with experimental data. The FLIR K55 thermal imaging camera was used to measure the temperature at the cotton curtain surfaces during the experiment. The temperatures were measured for two cases, i.e. the temperatures of curtain at the lower window in case of separation distance of $7 \mathrm{~cm}$ (full-scale distance of $3,5 \mathrm{~m}$ ) and the temperatures of the curtain at the upper window in case of distance of $8 \mathrm{~cm}$ (full-scale distance of $4,0 \mathrm{~m}$ ).
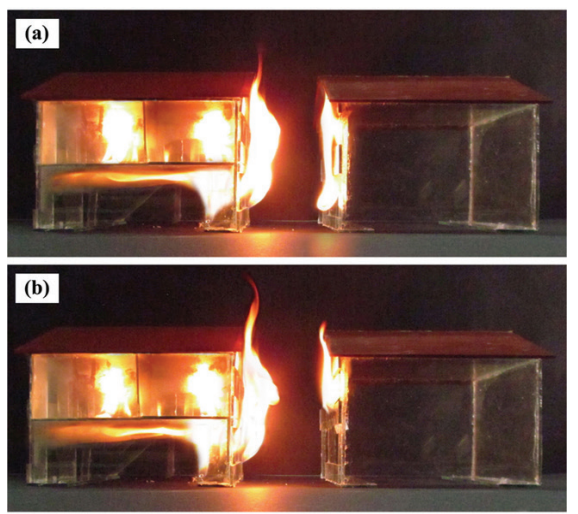

Figure 3 Curtain ignition (a) lower window; (b) upper window

The curtains' ignitions obtained during the wind tunnel experiment are shown in Fig. 3.
Two mesh size of $0,2 \mathrm{~m}$ and $0,1 \mathrm{~m}$ were subsequently used for both model validation and grid-sensitivity analysis. The simulation results compared to the experimental data are shown in Fig. 4.

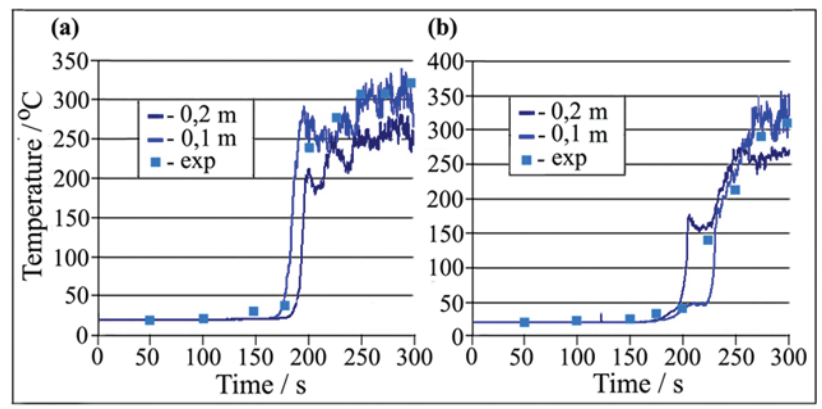

Figure 4 Grid sensitivity analyses: (a) lower window; (b) upper window

The grid of $0,2 \mathrm{~m}$ calculated by Eq. (8) can be taken as a reasonable grid size. Hovewer, the mesh size of $0,1 \mathrm{~m}$ shows better agreement between the simulations and the experiments. Therefore, for purpose of this investigation, the finer uniform grid size of $0,1 \mathrm{~m}$ was used due to higher velocity and temperature gradients close to fire source. The total number of grid cells was 2073600 (192 $\times 120 \times 90$ in the $x, y$ and $z$-direction, respectively).

\section{Results and discussion}

The maximum radiation heat flux from a burning building to an adjacent building occurs during the fullydeveloped fire phase. Therefore, for investigation of fire spreading, it is very important to predict the dynamics and temperature regime of the fire.
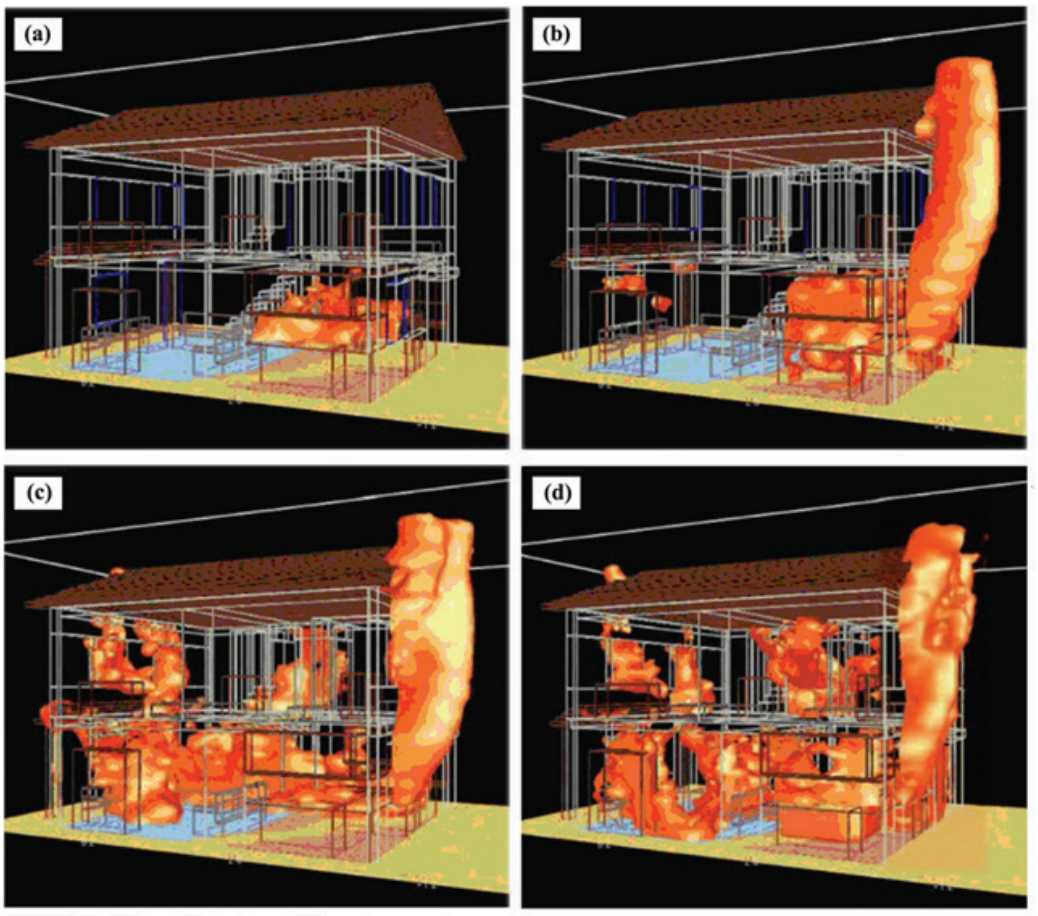

Figure 5 Fire development

The simulation results of fire dynamics inside the burning building are shown in Fig. 5. The fire was originated by an ignition of vapour that was generated over the cooking oil surface. The HRR of the oil was 400
$\mathrm{kW}$ and the radiative and convective heat fluxes on the kitchen cabinets surfaces were induced by the spruce pyrolysis. Piloted ignition occurred when pyrolysis gases were released from the wooden cabinets at a rate which is 
sufficient to produce a flammable mixture. After the ignition, the fire was spread over the cabinet surfaces and the whole kitchen was overwhelmed by the fire (Fig. 5a).

Since the kitchen window glass pane was exposed to the fire, its temperature increased. Due to uneven thermal expansion between the top and the lower glass layers when the temperature of the upper glass surface reached $450{ }^{\circ} \mathrm{C}$, the window glass got broken [26]. The glass breakage resulted in a change of the fire dynamics in the building. The fresh ambient air entered the kitchen through the lower part of the window. The quantity of oxygen that is available to the fire was increased. This resulted in faster combustion of furniture and rapid increase of temperature. The fire was spread to the dining room after it completely engulfed the kitchen. Later on, since the doors inside the building were open, the fire spread to the living room and the other rooms at the first floor (Fig. 5c).

On the other hand, after the window glass breakage, the greater air density created a positive pressure in the kitchen which caused the buoyancy-driven flame and plume to go out through the window and move upwards along the facade of the building (Fig. 5b). The hot flame influenced the breakage of the window glass in the firstfloor bedroom. Subsequently, the flame entered this room and caused the ignition of the curtain and the furniture. Finally, the whole building was fully involved in fire (Fig. 5d).

Since the radiation intensity is dependent on the temperature to the power of four, the fire temperature is a very important parameter to determinate the emitted radiation from a burning building.
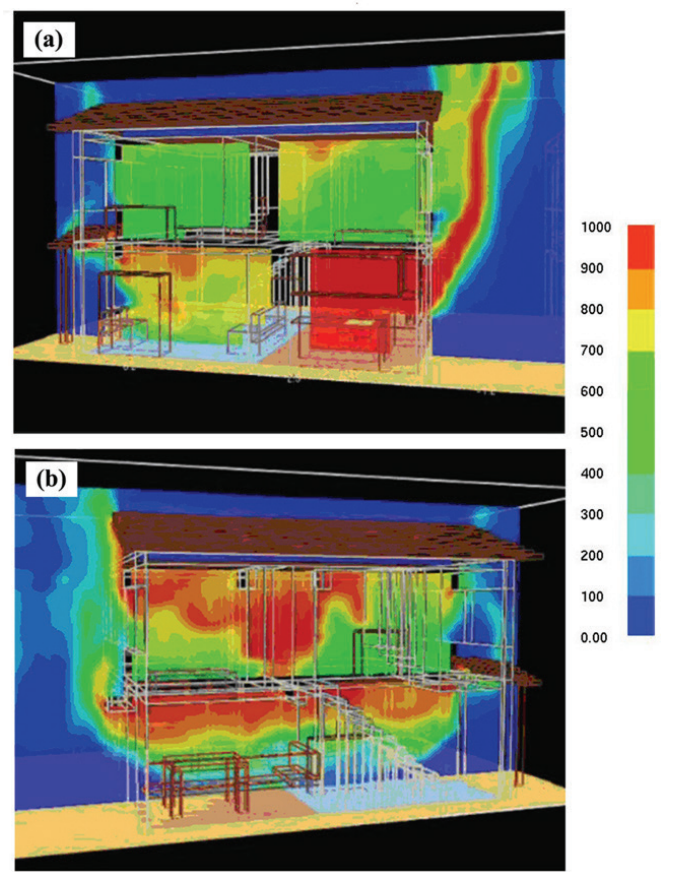

Figure 6 Temperature fields in vertical plane: (a) 3,9 m; (b) 8,1 m

The results of temperature regime in fully-developed fire phase which is visualized through time-averaged temperature fields of fire flame and plume in vertical planes 3,9 $\mathrm{m}$ and 8,1 $\mathrm{m}$ are shown in Fig. 6. It is obvious that there are a few parameters that affected the fire temperature in the burning building and consequently, the emitted radiation. The building geometry, as well as the number and the dimensions of the windows (i.e. the opening factor) had a great influence on the fire temperature. Since the doors inside the building were open, the quantity of air was enough to initiate combustion of the furniture in the fire growth phase. The furniture combustion generated the growth of fire and the increase in temperature. The opening factor influenced the fire temperature as well. Namely, due to continuous supply of the fresh air after all glasses were broken, the fire was intensified and the temperature was rapidly increased. The window dimensions also influenced the size of the flame projected from the window and the level of emitted radiation.

As it can be seen in Fig. 6, the maximum value of the fire temperature is about $1000{ }^{\circ} \mathrm{C}$. This temperature causes radiation intensity inside the burning building and the window fire flame of $168 \mathrm{~kW} / \mathrm{m}^{2}$ [27]. The flame projected out of windows in the burning building may cause ignition by emitting radiation to the adjacent building, thus leading to fire spread.

The simulation results of fire spread for cases of building distances of $3,5 \mathrm{~m}, 4,0 \mathrm{~m}$ and $4,5 \mathrm{~m}$ are shown in Figs. 7, 8 and 9 .
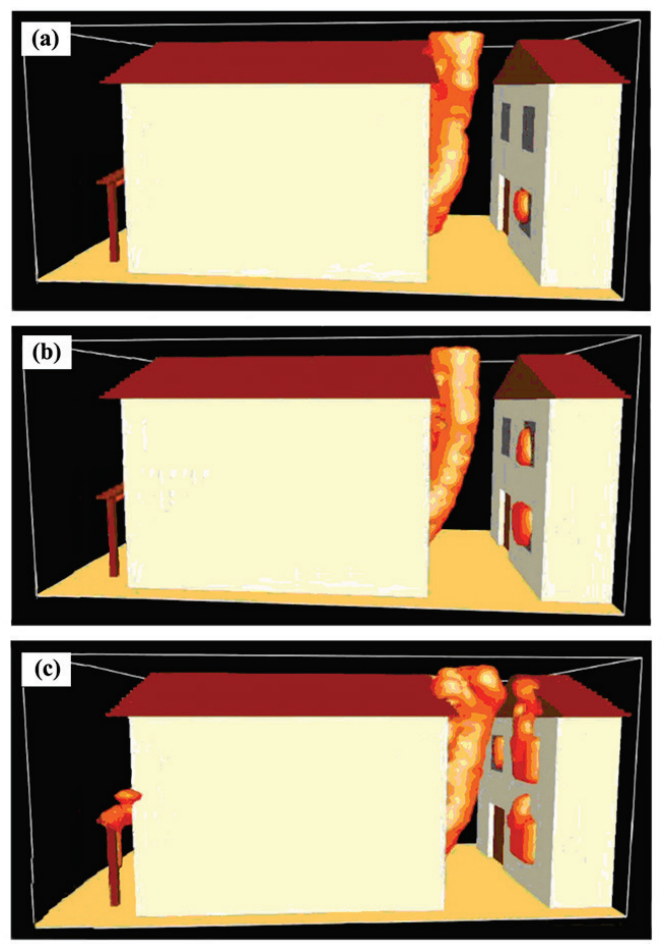

Figure 7 Fire spreading at buildings distance of 3,5 m

The simulation results show that, in the cases of distances of $3,5 \mathrm{~m}$ and 4,0 $\mathrm{m}$, the fire was spread from the burning building to the adjacent building. In the case when the distance between buildings was $3,5 \mathrm{~m}$, after the kitchen window of the burning building was broken, the fire was primarily spread to the adjacent building by ignition of the curtain on the lower window (Fig. 7a). Later on, following the window glass breakage in the bedroom above the burning kitchen, the flame radiation caused the ignition of the upper-window curtain in the adjacent building (Fig. $7 b)$. Finally, after the window glass breakage in the second bedroom at the first floor of burning building, the fire spread on the window curtain above the door of the exposed building (Fig. 7c). 

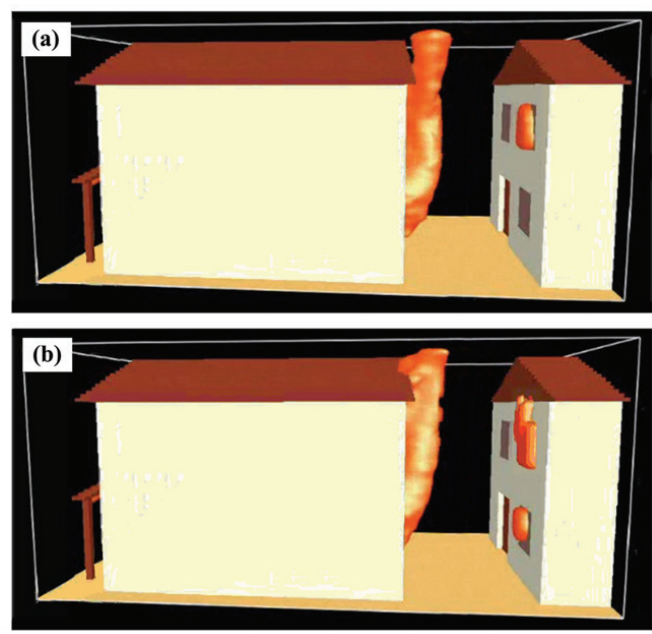

Figure 8 Fire spreading at buildings distance of $4,0 \mathrm{~m}$

The obtained results of the fire spread between the buildings with the distance of $4,0 \mathrm{~m}$ show that the fire was spread by igniting the cotton curtain on the upper window in the exposed building (Fig. 8a). The reason for this is the intense flame radiation due to the furniture combustion in the bedroom after the window glass was broken. Following this, due to the flame radiation, the curtain on the lower window was also ignited (Fig.8b).

In case when the distance between the buildings was 4,5 m, the fire did not spread (Fig. 9).

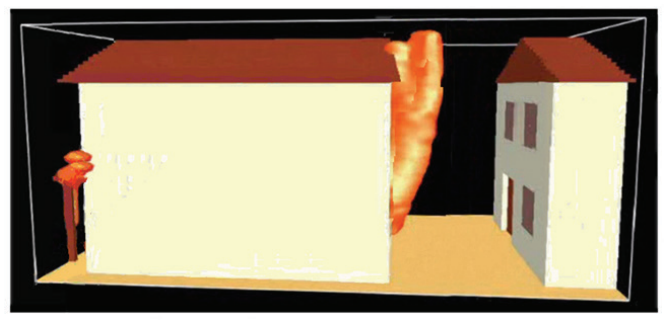

Figure 9 Fire spreading at buildings distance of 4,5 m

Fire spread between buildings occurs when the incident heat flux received by the adjacent building exceeds the ignition heat fluxes of the exposed materials; therefore, it is very important to predict the flux on the window curtains. The simulation results of the incident heat fluxes on window curtains of the exposed building after the kitchen window in the burning building was broken are shown in Figs. 10 and 11.

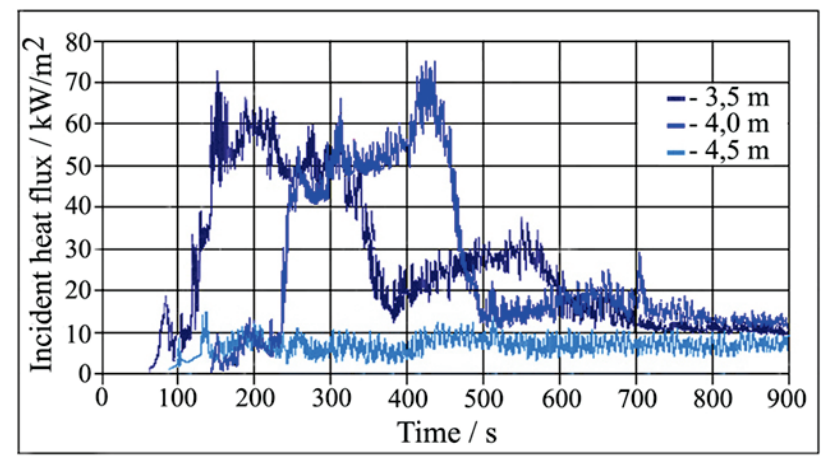

Figure 10 Incident heat fluxes of the curtain surfaces at lower window

The ignition of the window curtains occurred when the radiative flux at their surfaces reached the minimum value of radiative heat flux required for piloted ignition of cotton of approximately $10 \mathrm{~kW} / \mathrm{m}^{2}$ [28]. As it can be seen in Figs. 10 and 11, in case of building separation distance of $3,5 \mathrm{~m}$ and $4,0 \mathrm{~m}$, the curtains on the lower window in the exposed building were ignited in $70 \mathrm{~s}$ and $140 \mathrm{~s}$ respectively, after the breakage of the kitchen window glass of the burning building. On the other hand, the upper window curtains burned in $170 \mathrm{~s}$ and $110 \mathrm{~s}$, respectively. After the ignition of the cotton curtains, the heat fluxes were increased and in specific time intervals reached the values of approximately $70 \mathrm{~kW} / \mathrm{m}^{2}$. This value of the heat flux can induce the ignition of furniture in the exposed building.

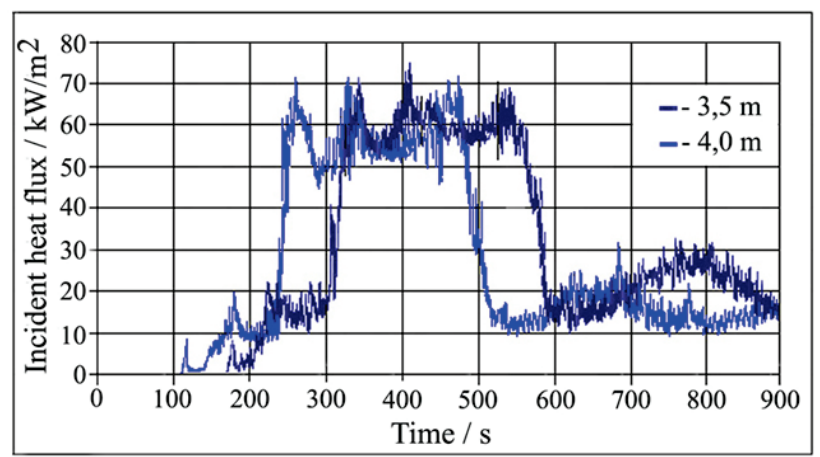

Figure 11 Incident heat fluxes of the curtain surfaces at upper window

In case of 4,5 $\mathrm{m}$ distance, the curtains in the fireexposed building were not ignited. However, the analysis of the obtained results of incident heat flux at the lower window curtain surface showed that its value in specific time intervals was approximately $14,0 \mathrm{~kW} / \mathrm{m}^{2}$. This value is higher than the critical heat flux value of $12,6 \mathrm{~kW} / \mathrm{m}^{2}$ adopted in many building codes. Also, the heat flux was higher than 8,0 $\mathrm{kW} / \mathrm{m}^{2}$ which was adopted as a maximum value of heat flux at the exposed curtain during the fire in the adjoining building [21].

\section{Conclusion}

The aim of this paper was to present the calculation methods for determination of separation distance between buildings given in many building codes and the possibility of application of numerical methods to determine the separation distance between residential buildings in terms of fire protection.

In case of fires with a relatively low fire load (less than $25 \mathrm{~kg} / \mathrm{m}^{2}$ ) various codes suggest that the value of the expected emitted radiation levels from burning residential buildings should be $84 \mathrm{~kW} / \mathrm{m}^{2}$. Nowadays, flammable materials are more complex and contain more energy and, therefore, it was essential to investigate the levels of radiation and temperatures that can be expected in residential building fire. The results of this study showed that the radiation level emitted from the residential building on fire is higher than the adopted value in the analyzed codes.

The numerical results also showed that the fire was spread from the burning building to the adjacent building in cases when their separation distances were 3,5 $\mathrm{m}$ and 4,0 $\mathrm{m}$. Serbian legislation requires that separation distance between residential buildings should be $4,0 \mathrm{~m}$ from the perspective of fire protection. However, the simulation results 
showed that the 4,0 $\mathrm{m}$ distance between buildings is not safe separation distance when fire spread from a burning building to an adjacent building.

It should be noted that this investigation did not include the presence of wind which strongly influences the fire spread and the total quantity of emitted and received radiation. The dimensions of the windows in the buildings were $1,4 \times 1,4$ $\mathrm{m}$, but the analyses of many experimental investigations proved that the window area had crucial influence on the radiative heat transfer. The quantification of these aspects could be a subject of further investigations.

\section{Acknowledgements}

This work is supported by the Ministry of Education, Science and Technological Development of the Republic of Serbia, Project No III43014.

\section{References}

[1] Approved Document, Part B: Fire safety. The Building Regulations 2000, 2006 edition. Department for Communities and Local Government, London, 2006.

[2] National Building Code of Canada. National Research Council of Canada, Ottawa, 2010.

[3] Building Code of Australia. Australian Building Codes Board, Melbourne, 1996.

[4] NFPA 80A: Recommended Practice for Protection of Buildings from Exterior Fire Exposure. National Fire Protection Association, Quincy, 2001.

[5] Shojaeefard, M. H.; Mirzaei, A.; Abedinejad, M. S.; Yassi, Y. Fluid flow modelling through an axial-flow microhydro turbine. // Tehnički vjesnik-Technical Gazette 22, 6(2015), pp. 1517-1526.

[6] ANSYS FLUENT 12 User Guide. AEA Technology, 2008, http://www.ansys.com.

[7] ANSYS CFX 11.0 User Guide. AEA Technology, 2008, http://www.ansys.com.

[8] PHOENICS Overview. CHAM Technical Report: TR 001, $\mathrm{http} / / /$ www.cham.co.uk/phoenics/d_polis/d_docs/tr001/tr00 1.htm.

[9] SMARTFIRE V4.1 User Guide and Technical Manual. Doc Rev 1.0, 2007.

[10] FIRE DYNAMICS SIMULATOR. National Institute of Standard and Technology, http://pages.nist.gov/fds-smv/.

[11] Zakon o zaštiti od požara, (Narodne novine, br. 92/10).

[12] Zakon o gradnji, (Narodne novine, br. 153/13).

[13] Zakon o lokalnoj i područnoj (regionalnoj) samoupravi, (Narodne novine, br. 19/13).

[14] Pravilnik o zahvatima u prostoru u kojima tijelo nadležno za zaštitu od požara ne sudjeluje u postupku izdavanja rješenja o uvjetima građenja odnosno lokacijske dozvole, (Narodne novine, br. 115/11).

[15] Prostorni plan Grada Zagreba (Sl. glasnik Grada Zagreba, br. 23/14)

[16] Prostorni plana uređenja Grada Splita, (Sl. glasnik Grada Splita, br. 31/05).

[17] Prostorni plan uređenja Grada Osijeka (Službeni glasnik Grada Osijeka, br. 12/12).

[18] Zakon o zaštiti od požara (Sl. glasnik RS, br. 111/09).

[19] Zakon o planiranju i izgradnji (Sl. glasnik RS, br. 72/09, 81/09, 64/10, 24/11, 121/12, 42/13, 50/13 i 98/13).

[20] Pravilnik o opštim uslovima o parcelaciji i izgradnji i sadržini, uslovima i postupku izdavanja akta o urbanističkim uslovima za objekte za koje odobrenje za izgradnju izdaje opštinska, odnosno gradska uprava ( $\mathrm{Sl}$. glasnik RS, br. 75/2003).

[21] Tehnička preporuka za zaštitu od požara stambenih, poslovnih i javnih zgrada. Savezni zavod za standardizaciju, Beograd, 2002.

[22] McGrattan, K.; Baum, H.; Rehm, R.; Mell, W.; McDermott, R. Fire dynamics simulator (Version 5) technical reference guide. NIST Special Publication 1018-5, Gaithersburg, 2010.

[23] Smagorinsky, J. General circulation experiments with the primitive equations: The basic experiment. // Monthly Weather Review. 91(1963), pp. 99-164. https://doi.org/10.1175/15200493(1963)091<0099:GCEWTP>2.3.CO;2

[24] BSI: Initiation and development of fire within the enclosure of origin, Application of Fire Safety Engineering Principles to the Design of Buildings, PD7974-1, Part 1. British Standards Institution, London, 2003.

[25] Šekutkovski, B; Kostić, I.; Stefanović, Z.; Simonović, A.; Kostić, O. A hybrid RANS-LES method with compressible k-omegaSSTSAS turbulence model for high Reynolds number flow applications. // Tehnički vjesnik-Technical Gazette 22, 5(2015), pp. 1237-1245.

[26] Pagni, P. J.; Joshi, A. A. Glass Breaking in Fires. // Fire Safety Science, Proceedings of the Third Int. Symposium / Washington, 1991, pp. 791-802.

[27] Law, M. Heat Radiation from Fires and Building Separation. Fire Research Technical Paper No.5, Joint Fire Research Organization, London, 1963.

[28] Nazare, S.; Kandola, B.; Horrocks A. R. Use of cone calorimetry to quantify the burning hazard of apparel fabrics. // Fire Materials. 26, 4-5(2002), pp. 191-199.

\section{Authors' addresses}

Dusica J. Pesic, Ph.D., Associate Professor

University of Nis

Faculty of Occupational Safety in Nis

Carnojevica 10a, 18000 Nis, Serbia

E-mail: dusica.pesic@znrfak.ni.ac.rs

\section{Darko N. Zigar, Ph.D., Assistant}

University of Nis

Faculty of Occupational Safety in Nis

Carnojevica 10a, 18000 Nis, Serbia

E-mail: darko.zigar@znrfak.ni.ac.rs

Miomir T. Raos, Ph.D., Associate Professor

University of Nis

Faculty of Occupational Safety in Nis

Carnojevica 10a, 18000 Nis, Serbia

E-mail: miomir.raos@znrfak.ni.ac.rs

\section{Ion Anghel, Ph.D., Assistant Professor}

Police Academy

Fire Officers Faculty

Privighetorilor Street, sector 1, Bucharest, Romania

E-mail: ion_anghe12003@yahoo.com 